\title{
POLICY REFORMS FOR SUSTANABLE IRRIGATION MANAGEMENT A CASE STUDY OF INDONESIA
}

\author{
Ramchand Oad'
}

\begin{abstract}
This paper is based on the results of a one-year study and analysis of irrigated agriculture in Indonesia (1997-98). The research was funded by the Asian Development Bank, and implemented with cooperation of the National Development Planning Board (BAPPENAS) and the Directorate General of Water Resources (DGWRD, Ministry of Public Works) in Indonesia. The overall purpose of the study was to review past policy approaches to irrigation development and management, evaluate their effectiveness, and recommend options for furture. ${ }^{2}$
\end{abstract}

\section{MACROECONOMIC CONTEXT}

Until mid-1997, the Government of Indonesia had made impressive progress in a number of social areas including poverty alleviation, employment generation and ensuring adequate access to food for the poor. Since the financial crisis in 199798, these trends are in reverse. One of the severest droughts in this century associated with El Nino and the unprecedented financial crisis dealt a severe blow to Indonesia's food security. Food and Agriculture Organization (FAO/WFP) Mission (1998) estimated that the country would need to import a record 4 million tons of rice for the 1998/99 marketing year. In addition to rice, Indonesia is importing other major food crops including maize and soybeans.

The events of 1997 and 1998 have changed the setting of agriculture and rural Indonesia in some fundamental ways. Decelerating economic activity, higher

\footnotetext{
I Professor, Colorado State University, Fort Collins, Colorado. The author was team leader of a nino-member interdisciplinary team that conducted the study in Indonesia.

2 Detailed information is available in the study team report: Consortium of International Development (1998). Assessenent of Options for Sustainable Irrigation Development in Indonesia (ADB TA 2679-INO). Final report submitted to the Asian Development Benk and the Government of Indonesia.
} 
prices and surging urban unemployment have propelled large numbers of households into impoverishment. Once again, the rural areas are characterized by mass poverty. Fortunately, the currency devaluation and tight liquidity in the financial markets should raise the relative returns to land and labor intensive activity, providing a sharp boost to economic incentives in rural agricultural sector.

The immediate priority is to cushion the fall in incomes and employment with a combination of food relief, job creation and the provision of essential foods at affordable prices. In the long run, to alleviate the crisis, policy makers must restore high-quality rural growth by promoting sustainable uses of land and water. Indonesia must return to a "back to basics" policy in which the agricultural sector is the main engine of growth. A resource-based recovery provides the best opportunity to stimulate a sustainable growth that addresses food security, poverty, and income distribution concerns. Historically, agriculture has driven rural economic growth. Irrigation, as a subsector of agriculture, plays a strategic role in improving national food security, especially for rice, by helping farmers increase food production and generate income.

\section{$\underline{\text { Rice Production and Consumption Trends }}$}

The growth rate of Indonesian rice production has declined since early $1990 \mathrm{~s}$, especially in Java. Paddy production in Java grew from 26.3 million tons in 1990 to 27.4 million tons in 1996, an average annual growth rate of $0.74 \%$. Off-Java, the growth rate for the same six-year period was 3.32\%. For all Indonesia, it was 1.76 $\%$ compared to $3-6 \%$ for the 1970 s and early 1980 s (Table 1). FAO (1998) report confirms these findings, "...in the 1990s, production bas fallen behind demand, with rice imports amounting to 1.8 and 3.0 million tons in 1994/95 and 1995/96 marketing years... With the productivity gains leveling off in the early $1990 \mathrm{~s}$ Indonesia's rice deficit showed a rising trend with the peak reached in 1995....". 
Table 1. Growth Rates of Rice Harvested Area, Production and Yields

\begin{tabular}{|c|c|c|c|c|c|c|c|c|c|}
\hline \multirow[b]{2}{*}{ Years } & \multicolumn{3}{|c|}{ Rice Harvested Area } & \multicolumn{3}{|c|}{ Rice Production } & \multicolumn{3}{|c|}{ Rice Yields } \\
\hline & Java & $\begin{array}{l}\text { Off- } \\
\text { Java }\end{array}$ & Indonesia & Java & $\begin{array}{l}\text { Off- } \\
\text { Java }\end{array}$ & Indonesia & Java & $\begin{array}{l}\text { Off- } \\
\text { Java }\end{array}$ & Indonesia \\
\hline & \multicolumn{3}{|c|}{$\%$} & \multicolumn{3}{|c|}{$\%$} & \multicolumn{3}{|c|}{$\%$} \\
\hline $1967-76$ & 1.42 & 2.7 & 1.92 & 7.2 & 5.8 & 6.59 & 6.97 & 3.0 & 4.56 \\
\hline $1977-86$ & 1.8 & 2.6 & 2.14 & 3.13 & 3.0 & 3.1 & 0.41 & 0.52 & 1.1 \\
\hline $1982-96$ & 0.54 & 2.7 & 1.53 & 2.17 & 4.25 & 2.97 & 1.66 & 1.5 & 1.4 \\
\hline $1987-96$ & 0.31 & 2.8 & 1.45 & 1.53 & 3.82 & 2.43 & 1.22 & 1.1 & 0.96 \\
\hline $1990-96$ & 0.14 & 2.58 & 1.29 & 0.74 & 3.32 & 1.77 & 0.61 & 0.73 & 0.47 \\
\hline
\end{tabular}

Source: Consortium for International Development, 1998. Assessment of Options for Sustainable Irrigation Development in Indonesia. Final Report presented to the Asian Development Bank and the Government of Indonesia. Vol. 1 of 3, p.3.

According to the FAO (1998) report, the fundamental reason for low growth rates is the leveling-off of productivity factors, i.e., cropping intensity and yields. Analysis additionally reveals that not only are cropping intensity and yields low, but they have been stagnant for a decade. Data presented in Fig. 1 confirm that average national paddy yields have remained at a level of 4.5 tons/ha since 1990 . For other important food crops, such as maize, yields have been stagnant at 2.2 tons/ha since 1989 and soybeans averaged 1.2 tons/ha. Information on cropping intensity indicates similar trends -- currently low and low for the last 10 years, 1.5 level for Java and 0.9-1.0 for off-Java. Nationwide it is about 1.18.

On the consumption side, it is estimated that the total population will expand from 198 million in 1996 to 262 million in 2020. Per capita rice consumption will expand from $151.6 \mathrm{~kg} /$ capita/year to a peak of $154 \mathrm{~kg} /$ capita/year around 2006 and then decline to $147 \mathrm{~kg} / \mathrm{capita} / \mathrm{year}$ as income increases and further urbanization takes effect. That is, total rice consumption will increase from 30.068 million tons in 1996 to 38.65 million tons in 2020 . At a conversion rate for paddy to rice of $65 \%$, this increase will require 46.26 million tons of paddy in 1996; advancing to 59.463 million tons of paddy in 2020 .

During the next five-year period, the rice consumption is estimated to increase at a rate of $1.45 \%$ per year - but over the next 25 -year period, the overall increase will average slightly less than $1.0 \%$ per year. Both of these rates are less than the 
expected population growth rate and therefore seem reasonable compared to other regional rice consuming countries.

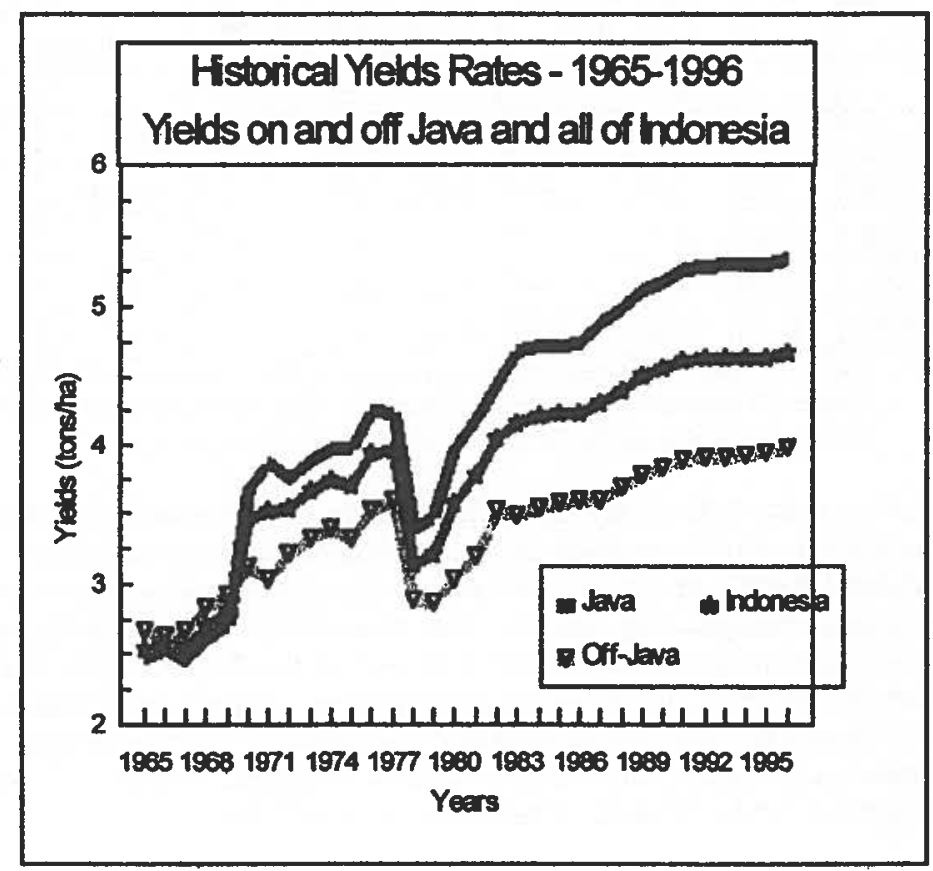

Figure 1. Historical Rice Yields, On-and Off-Java and All Indonesia

\section{Implications for Future Irrigation Development}

The study modeled several fiture development and management scenarios that can be employed by the government to balance expected consumption of rice and paddy production. The fundamental concern is to know whether rice selfsufficiency can be maintained through better management of existing irrigation resources, or there will be need to develop new irrigated lands. Following background information was used in the simulation exercises. 
- In the base model, annual rice yield growth rates are assumed to be $0.36 \%$ onJava and $0.96 \%$ off-Java;

- In the base model, annual rice cropping intensity growth rates are assumed to be $0.76 \%$ on-Java and $0.68 \%$ off-Java; and

- To assess agricultural land loss to urban and industrial use in Java, the model assumes three rates of land conversion. The first rate of $-0.57 \%$ (about 20,000 ha/year) is an estimate of land conversion over the past two years. The second rate of $-0.35 \%$ (around 12,500 ha/year) assumes a slowing of land conversion on Java. This slowing might result from financial crisis impacts and strengthened enforcement of the existing laws. The final rate of zero ha/year in land conversion is unrealistic but it dramatically illustrates the importance of protecting the good agricultural land on Java.

The results of the simulation exercise are presented in Table 2, and show the effect of increased yield and cropping intensity growth rates and additions and subtractions of land area on the future rice balance.

Option 1. Increasing Production with Constant Cropping Intensity and Yields The first development option assumes the cropping intensity and yield growth rates to be the same as the last few years (Base option in Table 1). The results indicate if the land area conversion on Java continues and there is no new land development off-Java over the next 25 years, the average rice shortfall will be 2.6 million tons/year. That is, with no improvement in crop yield and/or cropping intensity growth rate, it will be necessary to develop new land outside Java- about 60,000 ha/year from 1999 until 2020.

Since the implementation of Irrigation Operation and Maintenance Policy (IOMP) in 1987, Indonesia developed around 30,000 ha/year of new irrigated land. In contrast, the study suggests that the country will need to develop about 60,000 ha/year, at least up to 2010. This is only possible if much of the "new" development can actually be land completion in existing irrigation systems, where much of the infrastructure such as diversion weirs and main canals are already in place. The strategy of land consolidation has a good potential for increasing production, in a cost-effective way, and is discussed in detail in policy reform formulation section.

If the crop yields cannot be improved and the new lands cannot be developed, the remaining solution is to decrease the agricultural land loss in Java (scenarios 1-1 and 1-2). Even then, rice production will be less than estimated consumption both over the 5-year and 25-year period. 
Option 2. Increasing Production with Increased Yield and Cropping Intensity Another option for increasing production is to improve growth rates of crop yields and cropping intensity. If the country can obtain modest yield increases, say $0.24 \%$ per year (that is, improved growth rate of $0.6 \%$ for Java and $1.2 \%$ offJava), the amount of new land they need to bring in production is about 25,000 ha/year, which is feasible. The yield increases can result from introduction of new agricultural technology, better extension and irrigation management. The increase does not sound significant, but will increase yields in 2020 to 6.38 tons/ha on-Java compared to the base rate of 5.84 tons/ha and 4.95 tons/ha off-Java compared to the base rate of 4.8 tons/ha.

Even with faster yield increases, continued land conversion on Java will result in rice imports during the next five years. If the government slows land conversion to 12,500 ha per year along with an annual increase of 50,000 ha per year of irrigated land, this scenario could result in an average rice surplus of over 2.1 million tons/year throughout the 25-year period. 
Table 2. Required Irrigation Expansion under Different Development Scenarios

\begin{tabular}{|c|c|c|c|c|c|c|c|c|}
\hline \multirow[t]{2}{*}{$\begin{array}{l}\text { Options } \\
\& \\
\text { Scenarios }\end{array}$} & \multicolumn{2}{|c|}{$\begin{array}{l}\text { Annual Land } \\
\text { Additions \& } \\
\text { Subtractions (ha) }\end{array}$} & \multicolumn{2}{|c|}{$\begin{array}{l}\text { Constant yield and } \\
\text { CI growth rates }{ }^{1}\end{array}$} & \multicolumn{2}{|c|}{$\begin{array}{l}\text { Increased yield and } \\
\text { constant } \mathrm{CI} \text { growth } \\
\text { rates }^{2}\end{array}$} & \multicolumn{2}{|c|}{$\begin{array}{l}\text { Stagnant yield } \\
\text { and constant CI } \\
\text { growth rates }\end{array}$} \\
\hline & Java & Off-Java & $5 \mathrm{Yr}$. & $25 \mathrm{Yr}$. & $5 \mathrm{Yr}$. & $25 \mathrm{Yr}$. & $5 \mathrm{Yr}$. & $25 Y r$. \\
\hline $\begin{array}{l}\text { Option } 1 \\
\text { Base }\end{array}$ & $-20,000$ & 0 & -1143 & -2603 & & & & \\
\hline Scen. I.I & $-12,500$ & 0 & -949 & -1842 & & & & \\
\hline Scen. 1.2 & 0 & 0 & -522 & -549 & & & & \\
\hline $\begin{array}{l}\text { Option } 2 \\
\text { Scen. } 2.1\end{array}$ & $-20,000$ & 50,000 & -772 & -351 & -581 & 1300 & -680 & -3045 \\
\hline Scen. 2.2 & $-12,500$ & 50,000 & -531 & 410 & -343 & 2111 & -445 & -2317 \\
\hline Scen. 2.3 & 0 & 50,000 & -158 & 1673 & 39 & 3458 & -68 & -1107 \\
\hline Scen. 2.4 & $-20,000$ & 60,000 & -698 & 100 & -506 & 1757 & -605 & -2645 \\
\hline Scen. 2.5 & $-12,500$ & 60,000 & -289 & 861 & -268 & 2568 & -370 & -1916 \\
\hline Scen. 2.6 & 0 & 60,000 & -94 & 2124 & 113 & 3915 & 7 & -707 \\
\hline
\end{tabular}

Constant yield growth rates (Java $0.36 \%$ \& Off-Java $0.96 \%$ ); constant Cl growth rates (Java $0.76 \%$ \& Off-Java $0.68 \%$ ).

${ }^{2}$ Increased yield growth rates (Java $0.6 \%$ \& Off-Java $1.2 \%$ ); constant $\mathrm{Cl}$ growth rates (Java $0.76 \%$ \& Off-Java $0.68 \%$ ).

${ }^{3}$ Stagnant yield growth rates (Java $0.0 \%$ \& Off-Java $0.0 \%$ ); constant CI growth rates (Java $0.76 \%$ \& Off-Java $0.68 \%$ ). 


\section{IRRIGATION POLICY AND PERFORMANCE}

The food balance modeling exercise illustrates that while Indonesia will have to increase rice production to satisfy demand in the next 25 years, the country has a variety of viable options to meet the need. All scenarios require developing a limited amount of new land. However, if the country can slow agricultural land loss on Java and improve yield growth rates, a modest investment will be sufficient to fully utilize resources in schemes where irrigation facilities are already provided. All these findings imply a policy approach that focuses on better management of existing irrigation resources, rather than developing new resources. This realization is not new; in fact, it was the basis for the current IOMP policy formulated in 1987. Indonesia, with assistance from donor agencies, has made serious efforts to introduce more sustainable and efficient ways of managing . irrigation systems. The facts as previously presented, however, indicate that:

- In spite of the large public expenditures in irrigation system development, production growth rate of all major food crops including rice has declined, and

- The irrigation sector faces increasingly difficult challenges arising from the current financial crisis. It must restore momentum of food production, its security and self-sufficiency. And, it must do so with much reduced monetary resources.

Important questions are raised as these facts are considered: What fundamental reasons would explain this rather low performance of irrigated agriculture? What lessons can be learned from past experiences? And, what approaches in the future would improve system performance?

\section{Current Policy}

When Indonesia achieved rice self-sufficiency in 1984, the government had responsibility for managing 2.3 million ha of technical irrigation systems, and another 900,000 ha of semi-technical irrigation ${ }^{3}$. After this achievement there was a realization that to maintain and/or increase rice production, the government would have to shift to a policy of properly operating and maintaining existing irrigation systems. The Irrigation Operation and Maintenance Policy (IOMP) was

\footnotetext{
3 "Technical" irrigation systems are usually constructed by government agencies and have the potential of better water control in the sense that they are provided with flow regulation, measurement and other control structures. However, with better management, semi-technical and village irrigation systems may provide equally good or even better setvice to the farmers.
} 
introduced in 1987, and since then the Indonesian government and several major foreign donors have imvested large resources to support its implementation. The policy initiatives include following programs:

- Establishment and development of water users' associations (WUA),

- Irrigation system turnover,

- Irrigation service fees,

- Efficient operations and maintenance and needs based budgets, and

- System rehabilitation or special maintenance.

IOMP attempted to shift government irrigation roles from a construction to one of improved O\&M, cost recovery, and WUA involvement. The policy hoped to create new institutional roles and responsibilities for government personnel, and an expanded decision-making role for water users. However, IOMP has not lived up to expectations and its overall results with respect to ISF, institutional strengthening of WUAs and improved maintenance have been less than planned. Fundamentally, IOMP failed to establish a system of institutional incentives that favor efficient management over system extension, and proper maintenance over periodic rehabilitation. It did not establish the critical link between the consumers and the providers of irrigation service. Instead of empowering farmers, the original and innovative concepts of System Turnover to WUAs and ISF were used to justify more and more public funding for construction and system rehabilitation projects. Consequently, while government funding for system O\&M has continuousty increased since 1987, there has been no corresponding improvement in the quality of irrigation service provided to the farmers.

\section{Reasons for Low Performance}

To suggest future policy reforms, it is necessary first to understand why IOMP fell short of fulfilling expectations. Following major reasons were identified:s

\footnotetext{
4 The study estimated that IOMP has been supported by projects valued at U.S $\$ 2.12$ billion, of which $\$ 1.4$ billion were provided by ADB and the World Bank.

${ }^{5} \mathrm{~A}$ parallel ADB study of agriculture sector supports the finding that the combination of low irrigation system performance and poor agricultural support services have caused crop yields and intensities to stagnant (Ministry of Agriculture, 1998). Over the last eight years new tochnologies, especially high-yielding rice varieties, have not been introduced. Input costs are high compared to the prices that farmers receive for their produce, all of which are frequently controlled by government monopolies. Credit fecilities and marketing of agricultural produce remain major concerns for farmers.
} 
- The institutional setting and approach have not been supportive or appropriate.

- Implementation of the policy and strategy has not been done properly.

- Allocation of resources supporting IOMP has not been supportive.

- The policy has often been implemented incorrectly.

- The IOMP reforms have been too modest.

Inappropriate Institutional Setting and Approach. The mandate and responsibility for IOMP's implementation were never clearly defined, and there never has been an institutional "home" for IOMP in the Ministry of Public Works (DGWRD). Responsibility for each program is scattered among multiple central government agencies, and no one government agency has overall responsibility and authority for IOMP's successful implementation.

IOMP's planning and decision-makings have primarily been hierarchical and generally top-down. Local government officials and farmers are often unclear about their roles and responsibilities in the Turnover and ISF programs. For WUA establishment, for example, Ministry of Public Works, DGWRD offices (BinLak/PTGA and PPSDA) are responsible for planning, while the Ministry of Home Affairs (BANGDA) develops regulations for WUAs. Likewise, in the Turnover program, BinLak office in DGWRD is in charge of planning and decision-making for construction, but PPSDA (also in DGWRD) is responsible for the institutional aspects.

Misunderstanding of the Policy Content. There has been a general misunderstanding of IOMP's content. Though IOMP stressed mechanisms for increased funding for O\&M, the ultimate objective of the policy was improved O\&M performance and service. In the past 12 years, the funding focus took precedence over the performance focus, perhaps because of the incorrect perception that the increased funding will result in improved performance.

A good example of this misunderstanding of policy content is the ISF program. Originally planned to emphasize cost recovery from beneficiaries and improved service, the program has changed into a pure ISF collection exercise. The lack of improved service has caused farmers to withdraw from the program. It was envisaged that by year 1996, ISF program would provide major share for O\&M funds which would increase to $100 \%$ by year 2000 (Fig. 2). Data in Fig. 3 clearly shows that what has actually happened in O\&M funding is exactly opposite to IOMP expectations. It is still the central government, which finances irrigation system O\&M. 

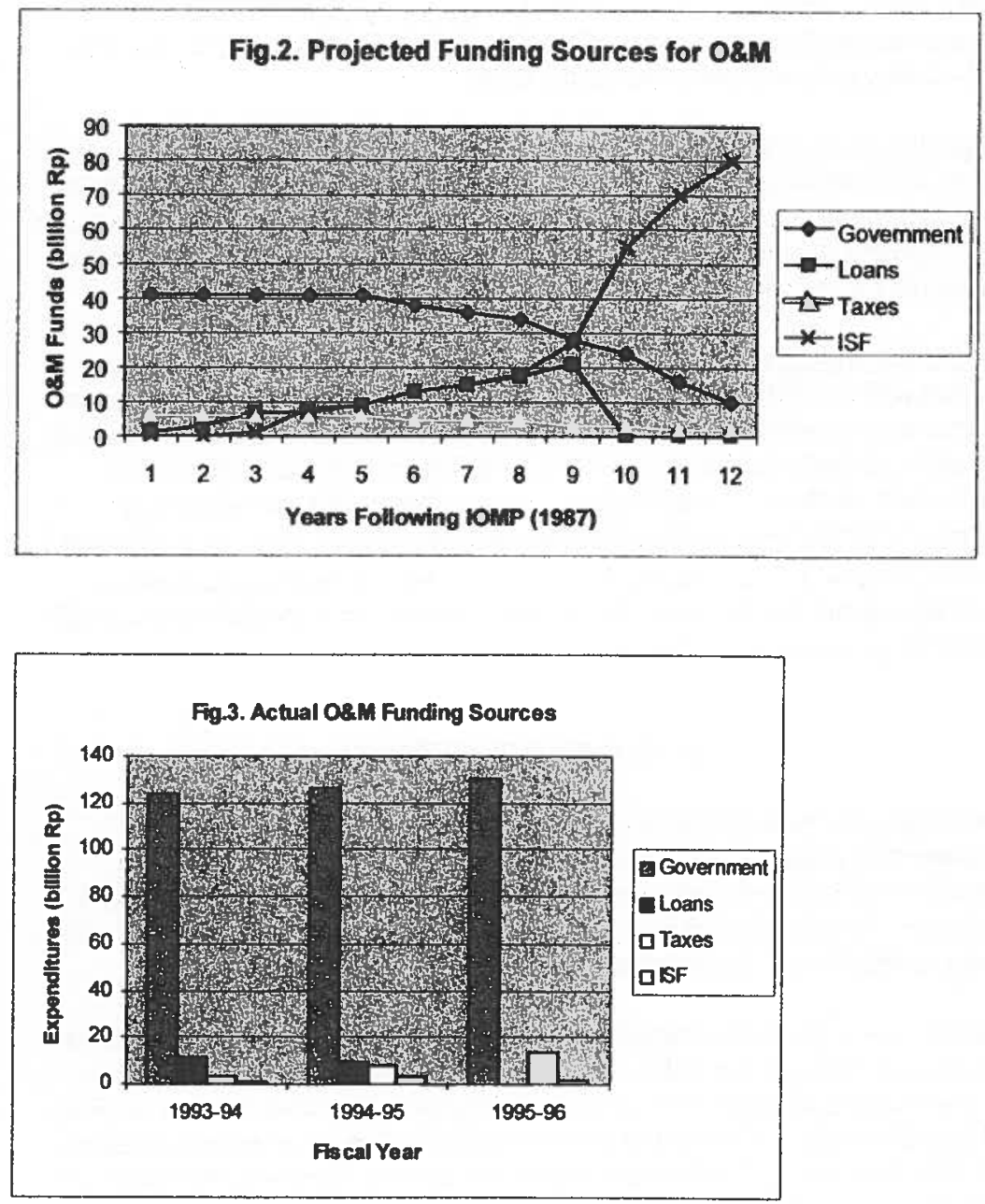

Inappropriate Allocation of Resources. In Indonesian government, budgets define programs. Budgets for IOMP institutional development activities (for example, farmer training) are extremely limited. WUA training budgets are less than $1 \%$ of construction budgets, and only $2 \%$ of system rehabilitation budgets in the World 
Bank's JIWMP Project. Even in JWMP's Turnover program, where WUA sustainability is absolutely crucial, WUA formation budgets are only $6-7 \%$ of the construction budgets (The World Bank, 1997).

Target-Driven Programs. IOMP institutional programs are often too targetdriven, and tend to neglect the policy's real objective - sustainable O\&M. IOMP performance monitoring has focused on items such as area coverage (ha), revenues (ISF collections), numbers of WUAs established, but has neglected to emphasize and monitor sustainability and better O\&M performance.

Too Modest Reforms. Despite the seemingly significant innovations introduced into Indonesia by IOMP (e.g. turnover of irrigation systems), in reality, the actual reforms are comparatively modest. In the ISF program, ISF collections become a part of the district's local revenue $(P A D)$, to be allocated and disbursed by the government. In the Turnover program, the government still maintains a large degree of control over irrigation functions, and the program began by emphasizing turnover of small 150 ha schemes. 6 WUAs have been given the opportunity to attain legal status, but few of the WUAs know what to do with that status and still rely on the government for direction.

\section{FUTURE POLICY REFORMS}

The fundamental issue for future policy reform is that even after massive investments in irrigation infrastructure and agriculture support programs, the growth rate of crop yield and cropping intensity have remained low for all major food crops. However, while past performance has been rather disappointing, study findings indicate valid opportunities for increasing food production.

There is a good potential for improving rice yields and cropping intensity, both in. and off-Java. Average rice yields of 4.0 tons/ha off-Java and 5.5 tons/ ha in Java are low for lowland paddy, $78 \%$ of which is irrigated. Yet, in some areas of Java and Bali rice yields of 8 tons/ha have been reported. Current cropping intensities of 1.7 for Java and 1.3 for the outer islands also are low. Cropping intensities of 2.5 in irrigated towlands of Java-Bali and 2.0 in irrigated lands outside Java are possible.

\footnotetext{
6 This might be compared to Nepal's Irrigation Management Transfer Program, where irrigation systems of 10,000 ha size have been turned over to farmers.
} 


\section{Strategy and Programs}

Large extension of irrigation system will not be a feasible strategy for increasing crop production, at least the next five or more years. The government simply will not have the funds to develop new irrigation schemes. A primary option for the irrigation sector, therefore, is to increase food production through better management of its existing resources; that is, improve crop yields and cropping intensity. This is an appropriate strategy since major problems with crop production seem to be due to inadequate management of irrigation resources and inadequate agricultural support services.

The emphasis on system management has been advocated before. Indeed, it was the primary motive behind the 1987 introduction of IOMP. So, what current actions will help ensure improved management and not merely justify more construction?

Evidence indicates that public management of the irrigation subsector has been less than effective. The future policy must try the other available option -- namely, empower WUAs with responsibility for O\&M of their irrigation schemes. The current policy fails to recognize the central role of farmers in irrigation development and management. IOMP needs to be reformed in order to promote the centrality of farmers within irrigation management. Briefly stated, the fundamental strategy of the Reformed IOMP would be to:

- Empower WUAs for better O\&M in order to increase productivity of irrigated agriculture, and

- In the context of better management, consolidate existing irrigation resources for optimum use of available land and water resources.

Fundamental policy approach would be to develop incentive systems that empower WUAs to routinely maintain irrigation schemes and provide reliable water supplies to the members. Also, WUAs and federations of WUAs need to be involved in the provision of quality agriculture support services so that the users have access to better seeds and other inputs, at reasonable prices. In the long run, federated associations can use their economies of scale to help their members to establish market opportunities for non-rice crops. To support implementation of this policy, the study recommended five programs. 
- Empower and strengthen WUAs

Institute a system of water rights that formally recognizes the rights of WUAs to manage public waters,

Expand the rights of WUAs to institute proper O\&M programs, and Involve WUAs in requesting and supporting system rehabilitation.

- Expand and accelerate Irrigation Turnover program,

- Accelerate Irrigation Service Fee program with WUAs collecting and managing the funds,

- Promote capacity-building programs to strengthen WUAs, and

- Complete land and water resources in existing irrigation systems.

\section{Development of Sustainable WUAs/WUA Federations}

One clear finding from the study team's field investigation was that a strong WUA is an excellent indicator and predictor for improved O\&M performance. The overall goals of a WUA development program would be: (1) improved, sustainable O\&M performance, and (2) increased farmers' income. The team recommended following strategies for WUA development.

Empower Farmers and WUAs. Government regulations should empower WUAs legally and economically. WUAs should be authorized to collect necessary management fees from their members and use it for proper system O\&M. Helmi (1997) has suggested a three-stage process to encourage WUAs seeking increased income. First, WUAs should become proficient in routine O\&M activities.

Second, the WUAs need to request Government assistance in income producing activities directly related to water, for example small water storage reservoirs that can also function as fish ponds. The final stage would be to facilitate WUAs and Federated WUAs involvement in larger agricultural activities such as accessing inputs and marketing produce.

Direct WUA Assistance Programs.. The establishment and development of WUAs should not promote a dependency on the government. Rather, government assistance programs to WUAs should be in response to requests from the WUAS and focus on activities that the WUAs can and should perform on their own - for example, irrigation functions, bookkeeping for income generation activities, and the legalization process.

WUA Federations. As WUAs take on added responsibility and authority in the Reformed IOMP, it is likely that WUA federations will play a larger role. With the current size of WUAs at only 50-150 ha, the organizations are too small to have a 
significant impact and to be able to recruit professional staff. WUA development efforts, therefore, should include specific programs to establish and develop larger WUA federations that can hire professional management staff while the members ensure the system is governed properly.

Region-Specific Initiatives. WUAs or traditional farmer irrigation groups behave in unique ways in different parts of Indonesia. The WUAs should be village based and incorporate and integrate local traditions into their development programs. It is critical that all WUA and WUA federation development programs and activities address the needs of the users and the villages, not the needs of the government.

\section{Accelerated Turnover Program}

Despite real problems in its implementation, much of the basic philosophy of turnover program remains sound. The program's goals and objectives are clearly in line with the Reformed IOMP's overall principles of farmer-based development and self-reliance. The accelerated turnover program would be based on the following strategies and reforms.

Tumover First, then Physical Improvements. The key to developing a more sustainable turnover program was adequately described by farmers: first develop a strong WUA, and then let the farmers request assistance from government for physical improvements. The current procedure of rehabilitating a system first before turning it over sends wrong signals to farmers and government staff.

Turnover of larger irrigation systems. There should not be any limitations on the sizes of irrigation systems turned over. The current approach of focusing on schemes 150 ha to 300 ha should be replaced with an incentive structure where district-level irrigation offices are rewarded for turning over larger schemes, even over 5,000 ha. In very large systems such as Jatilahur it is possible to have a two phase transfer program with WUAs taking responsibility for the secondary canals first, and a federated WUA eventually taking responsibility for the primary canals.

Farmers' Contributions in Physical Improvements. WUAs ned to be involved in physical improvements, inchuding formalized cost-sharing arrangement. Farmers requesting improvements will be expected to make an equity contribution, either in cash, labor, and/or materials. In the second Irrigation Sub-Sector Project (ISSPII) project, the World Bank estimated that the level of farmer equity contribution was about $9 \%$ of the construction cost. The contribution was mainly land and labor. 
Role of the Government. Government irrigation officials would take on new roles as advisors, trainers, and supporters of the newly turned over WUA-managed schemes. The government would maintain control of the headworks and weirs since river flows and downstream users would be affected. Presently, after rehabilitation and turnover, the government budgets for a turned-over irrigation scheme are reduced to zero. In their new role of water resource managers, local or semi-private agencies will be provided a public budget as needed to manage the water resource system.

\section{Irrigation Service Fee (ISF)}

The Government has already issued instructions to expand and accelerate the present ISF program. These instructions are in line with the proposed Reformed IOMP program and its increased emphasis on management of irrigation systems. The overall goals of the expanded ISF program would be to:

- Improve irrigation service, management, and performance,

- Assist with O\&M funding, and

- Develop the philosophy among farmers that irrigation management is not free.

The principles and strategies that will guide the implementation of the ISF program would be as follows.

Simplify Institutions and Procedures. The ISF program should empower local institutions, including WUAs and WUA federations: this is its primary purpose. Government will assist, monitor, train, and provide guidance, but the true "executing agency" will be the WUAs themselves. The key decision-making body in ISF would be composed of representatives from the WUA or WUA federation with advice from local government officials (Camat, Kepala Desa), and local irrigation officials (Pengamat). This would be at the sub-district level; there is no need for a large, central bureaucracy with numerous forms, rules, and procedures. WUAs will collect and manage ISF. 
Establish a Clear Link between the Providers and Consumers of Service. ISF should concentrate on genuine $O \& M$ tasks and improved service and management, not on new construction. The fees collected from a scheme must all be used for improving irrigation service in that scheme.

\section{Improved System Q\&M}

Key elements of an improved O\&M program would be as follows.

Institutional Incentives. Irrigation O\&M is not exclusively a funding problem. If proper maintenance is not done, it is often because the current system of institutional motivation makes it a low priority item. The fundamental solution would be to reform the system of institutional incentives whereby routine maintenance becomes as attractive as construction projects. The first step would be to ensure that WUAs view themselves as the decision-makers. In the government, the functions of system development and management should be assigned to one local institution so that an evaluation of tradeoffs is optimally made.

Institutional Accountability. There is fundamentally no accountability from the suppliers of maintenance services to the users. IOMP tried to provide a direct link between the supplier and consumer of irrigation service by introducing ISF.

Irrigation service foe is the correct way of introducing the link, but its management by government agencies has resulted in failure. In the Reformed IOMP, the process will be reversed with WUAs responsible for collecting and managing ISF funds.

Adequacy and Use of O\&M Funds. It is correct that the government funds are not sufficient for proper O\&M, but more funds would not necessarily result in better performance and service. Institutional motivations are simply against routine maintenance, and that needs to be changed first. A related problem with main system O\&M is not only the lack of funds but also the way in which existing funds are used. Data indicate that well over $60 \%$ of the O\&M funds are used for operational purposes (salaries and office supplies, etc.), and the rest for construction related activities.

At present, there are central block grants (INPRES) available to district-level offices. Few if any, of these INPRES block grants are used for irrigation O\&M. It may be necessary to make specific INPRES grants for irrigation O\&M, ensuring that the funds are transferred directly to the district level offices and/or WUAs. 
Monitoring and Evaluation of O\&M Performance, There are a variety of ways to measure O\&M performance, but finding simple and practical methods to use for the diverse conditions of Indonesia has proved difficult. Further, it is important that data are regularly analyzed and used to improve irrigation system performance. This can be a very simple recording of basic information such as:

- Adequacy and reliability of water supply

- Cropping intensity

- Yields and farm incomes

- Functioning of WUAs including ISF collections

- Planned maintenance vs completed maintenance, and

- Conflict resolution.

\section{Resource Consolidation}

Optimum use of existing irrigation facilities is in tune with the Government's tight monetary conditions. There are several irrigation schemes where the actual irrigated area is reduced by incomplete canal systems, incomplete land development, and water shortage. Completing the necessary infrastructure and land development optimizes the use of land and water resources as well as takes advantage of the sunken investment. Where water shortage is a constraint, in many cases, providing small storage reservoirs can relieve it.

Table 3 summarizes reasons why the lands are not optimally used based on information from field visits. As expected, the reasons vary widely, but the common themes are as follows.

- Shortage of water is one major reason why some service areas are not irrigated. Most schemes are run-of-the-river systems and the abundant water supplies during the rainy season are not stored. Small off-stream storage reservoirs can be very effective in alleviating this constraint (Achmad Fagi, 1994).

- Tertiary channels and control structures are not provided, and the lands are not yet developed to paddy fields. Most often, however, some of these lands may be used for plantation crops such as coconut and coffee since rice is not as profitable.

- Incomplete main system including the absence of main water delivery canal and related control ficilities. Many irrigation systems are developed on a modular 
or "piecemeal" basis so that, in the first phase, only a weir and a limited length of main canal are built. The system is then enlarged in successive years, depending on the availability of project funds.

Table 3. Reasons for Incomplete Use of Irrigation Resources - Examples from Field

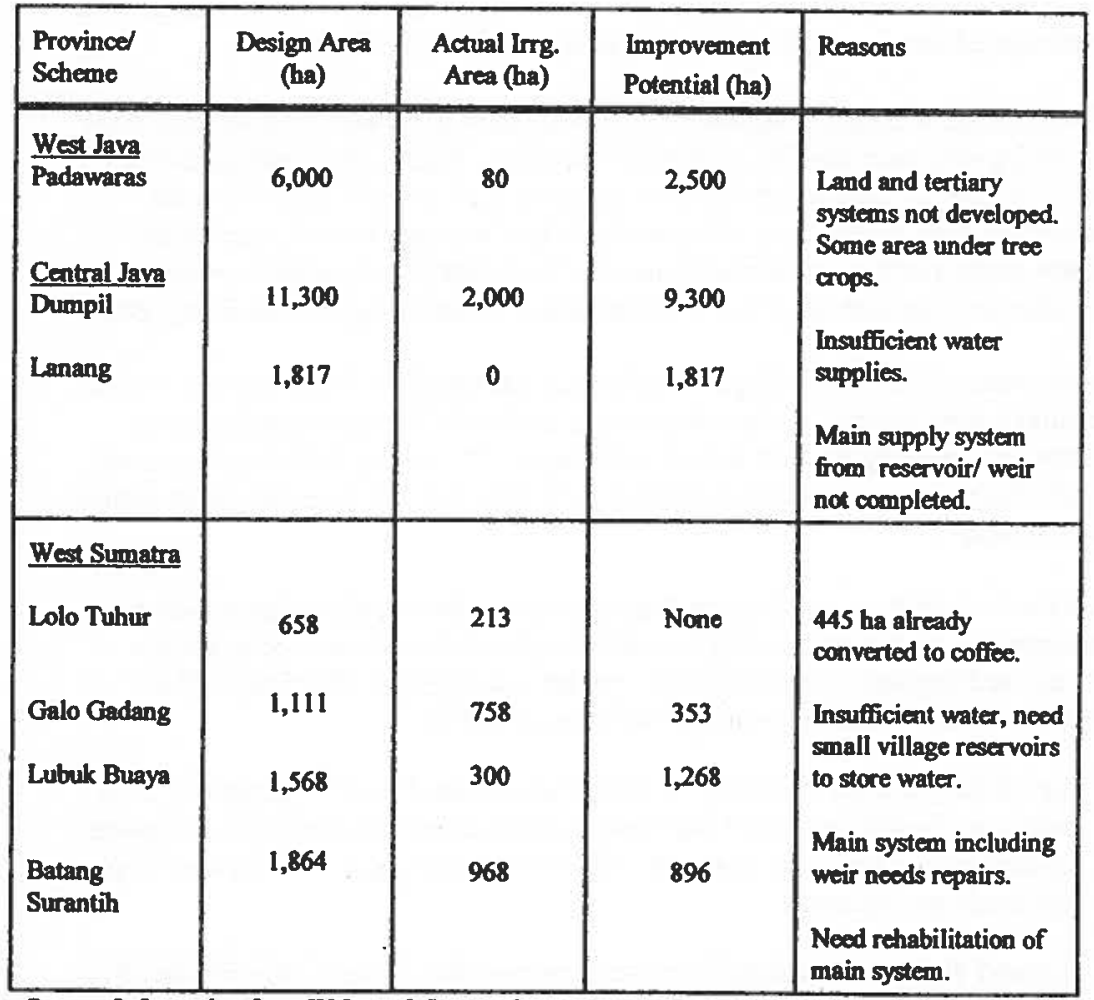

Source: Information from W.Java, C.Java and W.Sumatra Provincial Water Resources Services, 1998. 


\section{CONCLUSIONS}

Indonesian stakeholders must broadly rethink agricultural and rural development strategies. A resource-based recovery provides the best approach to stimulate economic growth and address food security, poverty, and income distribution concerns. Controlled prices and subsidies have confused the market and reduced farmers' economic incentives. Food security will not be achieved until the farmers know that they can make a reasonable profit. Policies to ensure fair prices must be implemented as a foundation for sustainable irrigated agriculture.

The challenge to irrigated agriculture in Indonesia is to sustain food security while expanding into more flexible, diversified cropping. Improving cropping intensity and yields, rather than developing new irrigated lands can efficiently increase Indonesian food production. Comparatively low cropping intensity and yields clearly imply a lack of good management of land, water, and production inputs. A fundamental emphasis on proper management of irrigated agriculture is required.

Public management of the irrigation subsector has been less than effective. Future irrigation policy should try the other option: enable the farmer communities to accept responsibility for their irrigation systems. The current IOMP policy needs to be reformed to promote the centrality of farmers and WUAs in irrigation system management.

Sustainable irrigation requires a system of institutional incentives that establishes accountability in the relationship between the providers and users of irrigation service, and inspires them to properly operate and maintain irrigation facilities. Reformed IOMP would encourage following programs.

- Reinforce the commitment to the Irrigation Service Fee (ISF) program. This means a simplified program that ensures funds raised are used in the irrigation system where they were collected, with the users having a final say over how the funds are expended.

- Expand the successful Irrigation Turnover program to eventually include all public irrigation systems. The size of the schemes need not be a limiting factor. The program also needs redesigning so that no rehabilitation is done until after transfer, when WUAs can make inputs on the nature of improvements.

- Recognize the central role of farmers and their WUAs. WUAs should be in charge of their irrigation systems, with a federation of WUAs responsible for plaming water allocation and main canal maintenance in larger schemes. 


\section{REFERENCES}

Achmad Fagi, 1994. Embung (Small Water Reservoirs). Ministry of Agriculture Center for Research and Development of Food Crops, Bogor, Indonesia.

FAO/WFP, 1998. FAO/WFP Crop and Food Supply Assessment in Indonesia. FAO, Rome April 17,1998.

Ford Foundation, 1998. Participatory Strategies for Irrigation in Indonesia. P.T. Artama-LP3ES, Jakarta, Indonesia.

Helmi, 1997. Developing Sustainable Farmers Organizations for Irrigation Management: an Assessment of Indonesian Experience. National Seminar on Development and Management of Water Resources, sponsored by DGWRD, Ministry of Public Works, Jakarta.

JCA (Japan International Cooperation Agency), 1993. The Study for Formulation of Irrigation Development Program in Indonesia. Ministry of Public Works/ BAPPENAS, Government of Indonesia, Jakarta.

Ministry of Agriculture, 1998. Agriculture Sector Strategy Review, Ministry of Agriculture, Republic of Indonesia: Constraints and opportunities for further growth in agriculture, Study A-2. ADB TA 2660-INO. Hunting Technical Services, Ltd, Jakarta.

1998. Agriculture Sector Strategy Review, ADB TA 2660-INO:

Decentralization of agricultural support services. Hunting Technical Services, Ltd. Jakarta.

Tabor, Steven, 1998. Back to Business: Revitalizing Rural Development in Indonesia. Bulog, the National Food Logistics Agency, Jakarta.

Asian Development Bank, 1993. Project Completion Report of the Second Irrigation Package Project in Indonesia, June 1993. Loan No. 627-INO, PCR:INO 16003.

The World Bank, Agriculture Operations Division. 1997. A Review of Public Agricultural Expenditures in Indonesia. World Bank, Washington, D.C. 
The World Bank, 1997. Java Irrigation and Water Resources Management Project (JWMP) Mid-Term Review (MTR)-Mission Objectives, Office Memorandum, 26 May 1997.

\section{Acknowledgements}

The author is greatly thankful to his team members for their able assistance and hard work in Indonesia. The financial support of the Asian Development Bank and the institutional aupport of Colorado State University and Consortium for International Development are greatly appreciated. In Indonesia, Ministry of Public Works provided work place for the study team and BAPPENAS provided the overall supervision. Several government officials and farmers in North and West Sumatra, Lombok, and Java provinces provided invaluable assistance in collecting field information. Last but not least, the patience and support of his family is highly appreciated.

\section{Acronyms}

$\begin{array}{ll}\text { ADB } & \text { Asian Development Bank } \\ \text { BANGDA } & \text { Directorate for Regional Development, Ministry of Home Afrairs } \\ \text { BAPPENAS } & \text { National Development Planning Board } \\ \text { BNLAK } & \text { Regional Directorates of DGWRD (western, central and eastern regions) } \\ \text { BULOG } & \text { National Logistics Agency } \\ \text { DGWRD } & \text { Directorate General Water Resources Development, Ministry of Public Works } \\ \text { EOM } & \text { Efficient Operations and Maintenance } \\ \text { FAO } & \text { Food and Agriculture Organization } \\ \text { INPRES } & \text { Presidential Instruction } \\ \text { IOMP } & \text { Irrigation operation and maintenance policy, 1987 } \\ \text { ISF } & \text { Irrigation Service Fee } \\ \text { ISSPI-I \& II } & \text { Irrigation Sub-Sector Project I \& I } \\ \text { JCA } & \text { Japan International Cooperation Agency } \\ \text { JWMP } & \text { Java Irrigation Water Management Project } \\ \text { MOA } & \text { Ministry of Agriculture } \\ \text { O\&M } & \text { Operations and Maintenance } \\ \text { PPSDA } & \text { Subdirectorate of Institutions in the Dir. of Utilization and Preservation, } \\ \text { PTGA } & \text { Proyek Tata Guna Air (Water Users Training Program) } \\ \text { WUA } & \text { Water Users Association }\end{array}$

